\title{
Asynkron e-læring: Skriften på nettet?
}

\author{
Stig Borsen Hansen, adjunkt, Institut for Filosofi, Padagogik og Religionsstudier, Syddansk \\ Universitet
}

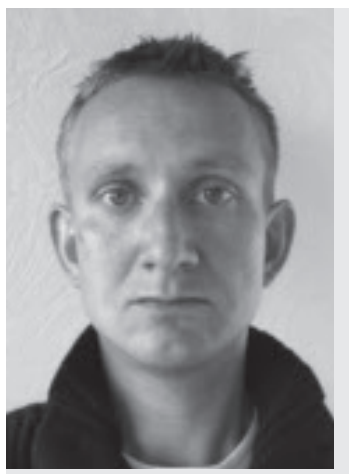

Stig Børsen Hansen er adjunkt filosofi på Institut for Filosofi, Pædagogik og Religionsstudier ved Syddansk Universitet. Han arbejder på et forskningsprojekt om filosofisk logik og religionsfilosofi. Han har undervist i teknologifilosofi ved universiteter i Danmark og England og er forfatter til The Internet Philosopher, skrevet for det britiske Higher Education Academy.

Indlaggets to forste afsnit presenterer Marx som ophav til en meget indflydelsesrig tradition inden for teknologifilosofien. Dernast vises, hvordan Marx' analyse af teknologi kan bidrage til belysningen af IT-baserede laereprocesser, hvor der her fokuseres på asynkron e-laring. For det forste fremhaves teknologiens centrale rolle $i$ et modsatningsfyldt forhold mellem brugere af teknologi og arbejdsgivere. Forestillingen om en okonomisk motiveret "deprofessionalisering " er her central. Dernost stilles der med udgangspunkt $i$ Langdon Winners teenkning sporgsmålstegn ved den opfattelse af teknologisk udvikling, der ofte synes at ligge til grund for diskussionen af IT på universiteterne.

\section{Indledning}

Formålet med dette indlæg er at præsentere et supplement til Nina Dohns (2007) filosofiske udgangspunkt for refleksion over asynkron e-læring. Baggrunden for nærværende bidrag er det voksende område, der betegnes som teknologifilosofi. Der er her tale om et forholdsvis nyt område i stadig udvikling, men der tegner sig tre toneangivende traditioner: Den fænomenologiske, som Dohn tager udgangspunkt i. Her har Heidegger været skelsættende, mens tænkere som Albert Borgmann og Hubert Dreyfus har forsøgt at videreudvikle og i forskellige sammenhænge anvende Heideggers tilgang. Dernæst gives den pragmatiske tænkning, hvor fx Dewey har været allestedsnærværende inden for den pædagogiske tænkning. Endelig gives den tradition, som Karl Marx indstiftede, givet ved de spørgsmål, han rejste. Nedenfor vil jeg søge at indikere, hvordan temaer fra Marx kan hjælpe til at belyse IT-baserede læreprocesser.

Marx er med nogen ret blevet tilskrevet den ære inden for teknologifilosofien, som Platon er inden for filosofien generelt: at have rejst de væsentlige spørgsmål inden for området og således sat dagsordenen for eftertiden. Utallige tænkere har forstået sig selv som "marxistiske tænkere", hvilket blandt andet skal ses i lyset af det brede spektrum af spørgsmål, Marx rejste og efterlod sig. For nutidige tænkere som Langdon Winner og Andrew Feenberg gælder det, at de har genrejst teknologifilosofiske spørgsmål fra Marx, og begge har bragt teknologifilosofiske antagelser i fokus. Alt imens er umiddelbart politiske og strategiske tanker angående samfundets indretning trådt $\mathrm{i}$ baggrunden og blevet forstået $\mathrm{i}$ intim sammenhæng med temaer fra teknologifilosofien.

At fokusere således på Marx' tænkning er på ingen måde at gøre vold på den, og ej heller kan den tilgang siges at være motiveret af en form for defeatisme på Marx' vegne: Centrale og omfangsrige dele af første bind af Marx' hovedværk Kapitalen (Marx, 1971) er tilegnet en historisk analyse af fremkomsten af maskinen og de konsekvenser, den generelt havde for arbejdslivet. Alt imens er den version af den kapitalistiske samfundsform, der her præsenteres, i det store hele krisefri og uden de store, revolutionære omvæltninger på horisonten. Formålet med nærværende artikel er således mere specifikt at klarlægge relevante dele af Marx' tænkning omkring teknologi med henblik på at analysere asynkron e-læring.

Asynkron e-læring kan ses som en udvikling af fjernundervisning via videobånd m.m., og grundlæggende vil jeg analysere situationen, hvor underviser og studerende adskilles i tid og rum, og hvor førstnævntes til tider repetitive arbejde med at forelæse søges erstattet ved brug af forskellige teknologier. Digital lagring af forelæsninger og brug af nye muligheder for distribution kan umiddelbart synes som emner og teknikker fjernt fra dem, der optog Marx. Ikke desto mindre vil jeg vise, hvordan temaer fra Marx stadig kan bidrage frugtbart til den diskussion, der har udfoldet sig blandt universitetsundervisere og potentielle brugere af den nye teknologi mere generelt. Som et filosofisk bidrag 
er formålet og strategien i første omgang at afdække vigtige antagelser $\mathrm{i}$ diskussioner af E-læring snarere end at analysere data eller levere konkrete forslag til pædagogisk praksis. Ej heller er det her opgaven at afsige nogen endelig dom over nye teknologiske tiltag. Snarere er formålet at påpege væsentlige elementer $\mathrm{i}$ en sådan vurdering.

\section{Marx om arbejdet}

Jeg skal her, med henblik på at forstå store dele af nutidig tænkning om asynkron e-læring og teknologi generelt, kort opridse nogle centrale træk af Marx' analyse af ændringerne $\mathrm{i}$ arbejdsformen under kapitalismen. Man skal være opmærksom på, at Marx ikke gør krav på præcis historieskrivning, men det han ville kalde analytisk historie (Mackenzie, 1996). Det, der drev megen udvikling på Marx' tid, var det faktum, at to klasser var opstået, hvoraf den ene - karakteriseret som den der besad snarere end benyttede produktionsmidlerne - var i stand til at skabe stigende merværdi ${ }^{1}$ ved at ændre på den måde, hvorpå der blev produceret varer. Kulminationen af disse ændringer var introduktionen af maskinen på fabriksgulvet, og udviklingen til dette punkt blev beskrevet som et forløb gennem forskellige stader.

Gennemgangen af staderne er overordnet en fortælling om skiftet fra arbejderens brug af redskab til maskinens brug af arbejderen. I første omgang sker denne udvikling ikke gennem en forandring af arbejderens redskaber, men gennem det, Marx kalder »kapitalens formelle underkastelse af arbejdet«. Forandringen var formel i den forstand, at økonomiske bånd var forandrede, alt imens de tekniske omstændigheder omkring den materielle bearbejdning af naturen var den samme. Dernæst følger to stader, henholdsvis manufaktur og industri, begge drevet af ønsket om større merværdi til ejeren af produktionsmidlerne. Under manufaktur er arbejderne blevet placeret under samme tag, og samarbejdet orkestreres af den nyligt opståede funktion, der varetages af manageren. Centralt for manufaktur er arbejdsdelingen, hvilket resulterer i, at det er et snævrere spektrum af færdigheder, der afkræves håndværkeren, når han skal udføre sit arbejde. ${ }^{2}$

En fin-inddeling af arbejdsprocessen muliggør ansættelsen af mindre kvalificeret arbejdskraft. Måske endnu vigtigere er det, at denne proces lægger grunden til introduktionen af maskinen. Derved overkommes nogle af de begrænsninger, der trods alt findes, når kapitalisten forlader sig på menneskelige delarbejdere: Fx kunne strømpemaskinen nu benytte flere tusind nåle på én gang, spinderokke kunne arbejde med et stigende antal spindler etc. Damp-kraftmaskinen har eksisteret siden slutningen af det 17 . århundrede, men Marx tilskriver den tekniske udvikling til fremkomsten af nye værktøjsmaskiner. I al korthed var damp ikke drivkraften i den tekniske revolution. Det var erstat- ningen af den menneskelige hånd med stadigt mere specialiserede værktøjer, der drev udviklingen. Mens manufaktur produktionen havde reduceret evnerne og selvstændigheden hos arbejderen gennem forandrede sociale arrangementer, trådte maskinen nu til og fortsatte den udvikling med andre midler.

Konsekvenserne af denne udvikling var følgende. For det første kunne flere grupper gøre deres indtog på arbejdsmarkedet, og deltagelse af kvinder og børn i produktionen havde store sociale og økonomiske konsekvenser. For det andet var der tale om det, sociologer senere har kaldt deskilling. Dette er det svært oversættelige udtryk for den proces, der som følge af maskinel produktion siges at have fundet sted blandt arbejdere. ${ }^{3}$ Hos Marx er det forbundet med arbejdsdelingen og den erstatning af håndværkeren, den med tiden muliggjorde. Resultatet bliver "en produktionsmekanisme, hvis organer er mennesker« (Marx, 1971, s. 501). Karakteren af arbejdsdelingen kommer til at minde mindre og mindre om de håndværk, der oprindeligt lå til grund for den, og der er mod slutningen af skiftet fra særoperation til maskinproces slet ikke tale om håndværksmæssigt delarbejde. De evner, der før lå hos håndværkeren, besiddes nu kun i sin helhed af produktionsorganismen eller "totalarbejderen", hvis lemmer er arbejdere.

Der er forskellige aspekter af deskilling processen, der er værd at fremhæve særskilt. For det første er arbejderen ikke længere i stand til - på egen hånd - at producere en vare. Det er kun resultatet af de samlede særoperationer, der udgør en ting, der kan gøres til genstand for økonomisk udveksling. Dette faktum bliver mere prægnant, når man tager Marx' noget plastiske begreb om fremmedgørelse i betragtning. ${ }^{4}$ I al korthed er der med fremmedgørelse tale om en adskillelse af noget, der burde høre sammen, og én af manifestationerne af fremmedgørelsen under den maskinelle produktionsform er, at arbejderen adskilles økonomisk og produktionsmæssigt fra sit produkt. For det andet er deskilling også udtryk for en transfer af evner. Dette finder enten sted ved, at $\mathrm{fx}$ fabrikken i sin helhed nu er det subjekt, der besidder evnerne, som håndværkerne tidligere besad. Alternativt finder det sted, for så vidt manageren $i$ forskellige afskygninger $i$ en vis grad overtager de evner, som håndværkeren tidligere besad. Sidstnævntes "livsånder " bliver ødelagte af det ensformige arbejde (ibid., s. 505), og "manufakturen producerer derfor i ethvert håndværk, som den bemægtiger sig, en klasse af såkaldte ukvalificerede arbejdere som håndværksvirksomheden med strenghed udelukkede« (ibid., s. 516).

Med maskinens indtog er det så at sige dén, der sætter dagsordenen, mens de forskellige slags arbejdere i vid udstrækning er dens levende vedhæn - "en del af en delmaskine " der må følge trop: "I manufakturen og håndværket bruger arbejderen værktøjet, i fabrikken bruger maskinen ham» (ibid., s. 610). Maskinen 
arbejder i et givet tempo, og det bliver hurtigt ændret $i$ jagten på profit og som respons til begrænsninger $i$ arbejdstiden: "Det arbejde, der udføres af de beskæftigede $i$ fabrikkerne er tre gange større, end da man begyndte med fabriksvirksomheden. Maskinerne har utvivlsomt udført det arbejde, der ville have krævet millioners muskelkraft, men det har også i uhyre grad mangedoblet det menneskelige arbejde, der styres af maskinernes bevægelser« (ibid., s. 598).

Ifølge Marx’ forståelse er der stærke modsatrettede interesser mellem de to klasser, der hver især defineres ved deres forhold til produktionsmidlerne, og maskinen leverer for kapitalisten et effektivt middel i denne kamp. Maskinen kan bruges til at bryde den magt, en gruppe faglærte kan have hver for sig i kraft af deres værktøj, og når de optræder sammen og derved kan danne monopol på en særlig kunnen. Arbejdernes kamp begynder derfor at tage sig ud som en kamp mod maskinen, og den til tider voldelige bevægelse, Luddisme $^{5}$, fødes i 1811 som respons til maskinernes indtog $\mathrm{i}$ tekstilindustrien, der fortrængte de faglærte strikkere.

Brugen af teknologier som magtmiddel illustreres fint ved Langdon Winners (1986) studie af Cyrus McCormicks høst-maskinefabrik i Chicago i 1880'erne. Winner understreger, hvordan maskinen tilsyneladende introduceredes med det formål at knække arbejderen. Her introducerede man, under store omkostninger, en ny form for lufttryks-støbemaskine. Mens man normalt vil antage, at bevæggrunden for en sådan anskaffelse var den derigennem opnåede effektivisering, minder Winner om, at McCormick på netop dette tidspunkt lå $\mathrm{i}$ strid med det nationale fagforbund af jernstøbere. Maskinen producerede dyrere og dårligere produkter og blev efter tre års brug udfaset. Men den kunne bemandes af ufaglært arbejdskraft, og fagforeningen stod efter de tre år langt svagere.

Generelt er Marx’ diagnose følgende: „Kapitalens kommando på produktionsfeltet bliver nu lige så uundværlig som generalens kommando på slagmarken", hvilket har den bevidsthedsmæssige konsekvens for arbejderne, at " $[\mathrm{s}]$ ammenhængen mellem deres arbejder træder dem ideelt i møde som en af kapitalisten undfanget plan, praktisk som kapitalistens autoritet, som en fremmed viljes magt, en vilje der stiller deres aktivitet i sit eget formåls tjeneste." (Marx, 1971, s. 492). Automatisering af arbejdsprocesserne har således ifølge Marx grelle bevidsthedsmæssige og politiske konsekvenser, og analogien med krigsførelse - en analogi ofte benyttet når talen falder på argumentation - trænger sig også til stadighed på $\mathrm{i}$ beskrivelsen af introduktionen af nye teknologier.

\section{Maskiner på universitetet?}

I 1920'erne spekulerede professor i pædagogisk psykologi, Sidney Pressey: »There must be an industrial revolution' in education in which educational science and the ingenuity of educational technology combine to modernize the grossly inefficient and clumsy procedures of conventional education" (citeret i Petrina, 2004 , s. 305). I den senere tid har især nordamerikanske akademikere ikke været sene til at se en lighed mellem elementer af den ovenfor skitserede udvikling og introduktionen af asynkrone, IT-baserede læreprocesser på deres arbejdsplads. (Winner, 2004, Feenberg, 2001, Noble, 2002 og især Simmons, 2001). Megen dansk diskussion har været præget af, at man har beskyldt IT-skeptikere for maskinstormeri, hvor det forstås, at noget sådant ultimativt vil have meget ringe effekt og $i$ øvrigt være præget af en vis tragi-komisk irrationalitet. ${ }^{6}$ For så vidt kritikken har været systematisk begrundet, har den i høj grad taget afsæt i overvejelser i stil med dem, man finder angående IT-baserede læreprocessers begrænsninger hos Dohn (2007). ${ }^{7}$

Med til den lighed, man har set mellem Marx' analytiske historiefortælling og nutiden, hører antagelser om en form for nødvendighed i den teknologiske og dermed samfundsmæssige udvikling. Dette er et af de mere kendte temaer fra Marx' filosofi generelt, men inden vi afsluttende behandler dette emne, må vi klarlægge, hvori den opfattede lighed består.

Den historiske baggrund for introduktionen af asynkron e-læring på læreanstalter er udviklingen af fjernundervisning til brug i områder præget af afstande større end dem, man finder i Danmark. Mens sådant materiale oprindeligt var baseret på papir og senere video, er der med internettet åbnet mulighed for udveksling af materiale på hurtigere vis og materiale af langt mere sofistikeret karakter. Endvidere gives der med fildeling og stigende båndbredde mulighed for at downloade forelæsninger, hvor de marginale omkostninger er langt lavere end ved distribution af fysiske lagringsmedia som dvd eller tidligere, video.

I slutningen af 1990'erne begyndte nordamerikanske og engelske universitets-administratorer og -ledere netop af hensyn til omkostninger at se andre muligheder i den digitale teknologi. ${ }^{8}$ Man så ganske enkelt muligheden af at generalisere fjernlæringsmetoden til at inkludere alle studerende, uanset opholdssted. I korte træk ville metoden være at lade en anerkendt professor give en »standard" forelæsningsrække inden for et centralt fag $i$ en given uddannelse, lagre den digitalt og genbruge den år efter år. Til afviklingen af et sådant fag skulle der ud over de lagrede forelæsninger knyttes en række relativt lavt kvalificerede undervisningsassistenter til at gøre arbejdet med at forklare yderligere, rette opgaver og eksaminere.

I korte træk og mere forretningsorienteret sprog så man muligheden af at erstatte "physical processes with new processes that can be accomplished over networks" og at unbundle services, der ellers typisk er integreret i underviseren. Dette ville erstatte professoren med deprofessionaliserede ${ }^{9}$ content experts (se Hamilton \& 
Feenberg, 2005, s. $98 f f$ for flere eksempler på visionære fortalere fra uddannelsessektoren). Når man til sådanne visioner lægger, at man i dansk sammenhæng har universiteter, der af økonomiske grunde i høj grad allerede er afhængige af dårligt organiserede, deltidsansatte og med tiden deprofessionaliserede undervisningsassistenter og eksterne lektorer, kan udstrakt brug af podcasting og lignende teknikker synes at være et næsten logisk skridt for ledere af universiterer - ledere der i stigende grad synes at imitere forretningsverdenen i deres strukturering af universiteterne. Endelig skal det bemærkes, at uddannelsessektoren gennem længere tid har været i søgelyset generelt hos kapitalforvaltere, og at en toneangivende forståelse her er, at "corporate training firms that focus on classroom-type training will shrink unless they adapt to e-learning " og videre at "in the online world, corporate traning programs are in the vanguard. But higher education isn't far behind". (Business week, "Education" 2000, Jan 10.)

Konsekvenserne af realiseringen af en sådan vision ville have mange lighedspunkter med den, vi fandt hos Marx: Flere vil kunne udføre det arbejde, der kræves for at uddanne studerende, hvilket med en vis sandsynlighed vil have konsekvenser for fagets aflønning og anseelse; de evner, underviseren besidder for så vidt hun udvikler, planlægger og underviser i et fag, ville blive forholdsvis sjældne, og endelig vil der ske en fremmedgørelse studerende og lærer imellem. Sidstnævnte ville i ringere grad kunne »spejle sig i sit produkt» og sige, $i$ en vis forstand kalde det "sit". Endelig vil resultatet af arbejdet - produktet - ofte være af en dårligere kvalitet.

\section{Teknologisk determinisme i diskussion af nye teknologier}

Sidney Presseys helhjertede forsøg på en uddannelsesmaskine fejlede, ligesom Storbritanniens e-universitet, UKeU, blev lukket i 2004 pga. manglende tilslutning. I Danmark lukkede en national portal for universitetskurser i 2002. Det kommercielle Apples Itunes $U$ har været mere succesfuld (dog på ganske andre betingelser) og et kursus af ovennævnte Hubert Dreyfus om eksistentiel filosofi ("Phil 7: Existentialism in Literature and Film«, fra UC Berkeley) lå i 2007 længe på førstepladsen over det mest downloadede kursus blandt podcasts om alt fra kvantemekanik til byplanlægning fra forskellige, ofte prominente universiteter.

Man ser til stadighed appel til en slags nødvendighed eller determinisme, når talen falder på teknologi. En tidlig fortaler for IT-baserede læreprocesser kunne således sige følgende:

"Universities are in the information business, and the information railroad is coming... we would be wise to ask whether the particularly quaint way that we manufacture, distribute and deliver that education will survive the arrival of the information railroad." (Wullf, 1998, s. 1f., citeret i Hamilton \& Feenberg, 2005, s. 98).

I dansk sammenhæng har podcasting-ekspert, Karin Høgh, i en vurdering af et forsøg med podcasting på Syddansk Universitet givet udtryk for at »det er, som om Danmark er faldet ned i et hul, og podcasting-toget er ved at køre hen over os". ("Podcasting ekspert: Se nu at komme i gang - der er intet at frygte Fyens Stiftstidende, 19.10.2007). At den teknologiske udvikling "er umulig at stoppe « høres ofte i uformelle sammenhænge, og $\mathrm{i}$ almindeligt sprogbrug finder man også tale om konsekvenser af nye teknologier på en måde, som man taler om konsekvens i logik: noget der følger med nødvendighed.

En sådan forståelse bør kvalificeres. Ingen teknologiske artefakter arriverer på verdensscenen ved egen kraft. De opfindes, markedsføres og ikke mindst formes af deres brugere. Teknologihistorien er fyldt med eksempler på teknologier introduceret med én slags brug for øje, mens den faktiske udvikling, præget af brugere, er gået $i$ en ganske anden retning. Blot et enkelt eksempel er det franske Minitel. Det blev hurtigt til et slags online dating bureau, hvilket ingen af dets skabere havde haft til hensigt. ${ }^{10}$ Selv Bill Gates tager fejl i sine forudsigelser og forståelse af historien gang, som Graeme Goodays studium af de forskellige udgaver af Bill Gates' The Road Ahead tydeligt viser (Gooday, 1998). Selve titlen leder ganske enkelt til en forkert slags tænkning om teknologisk udvikling som noget allerede givet - gennem en form for egen kraft eller gennem skabernes intention.

Forklaringen på, at tale om nødvendighed alligevel hersker, kan bl.a. findes i en distinktion, som Winner (1986) har introduceret i sin behandling af teknologisk determinisme. Valg af teknologi bør ifølge Winner reelt forstås som to valg: Hvorvidt man vil have en given teknologi og hvordan man vil have en given teknologi - teknologiens sociale omstændigheder og praktiske udformning. Og her gælder det, at valget af teknologier i nogle tilfælde bestemmer de sociale omstændigheder. Fx fremføres det ofte, at hvis man har sagt "ja " til atomkraft har man også - med noget der tilnærmer sig logikkens nødvendighed - sagt "ja» til et vist sikkerhedsapparat og en forladen sig på en lille, højtuddannet teknisk elite. I kontrast hertil er nogle teknologier langt mere plastiske i den måde, hvorpå vi har dem, og her synes brugen af IT at være i den plastiske ende af skalaen. Som introduktionen af Minitel i Frankrig også viser, synes tale om en nødvendig udvikling derfor upassende i denne sammenhæng.

Når jeg bruger udtrykket "noget der tilnærmer sig nødvendighed « er det begrundet $\mathrm{i}$, at tale om nødvendighed er langt mindre metodologisk frugtbart end det at tale om kompatibilitet mellem en given teknologi og samfundsmæssige og kommercielle strukturer. 
Flere har ment, at fx simple, decentrale teknologier generelt og decentrale energikilder specifikt er mere kompatible med demokratiske samfundsformer. Sådan tænkning kan i nogen grad forklare udtryk for determinisme med hensyn til teknologisk udvikling, men den afgørende pointe for både fortalere for og modstandere af fænomener som asynkron e-læring er, at der kun er tale om mere eller mindre stærke tendenser. Teknologisk udvikling er hverken at ligne med jernbaneskinner, skrift på væggen eller andre former for givethed. Den præges i overensstemmelse med forskellige aktørers mål og intentioner, og det er afgørende for en sådan prægen, at man forsøger at gøre sig klart, hvilke muligheder og farer der kan ligge $i$ en given teknologi. Kun i én blandt flere mulige, fremtidige verdener bruges asynkron e-læring udelukkende med snævert defineret produktivitet og effektivitet for øje. Også her har brugere - i dette tilfælde studerende og undervisere - stor mulighed for at præge den faktiske brug af teknologien.

Intentioner og mål med brugen af fx podcasting varierer en del blandt både undervisere, ledere på universiteter og politikere.Vi har set tænkning og intentioner, der kan give grund til at tvivle på, at Dohn har ret i at "geografisk og tidsmæssig fleksibilitet ... som oftest har udgjort den primære, hvis ikke den eneste grund til etablering af virtuelle læringsrum". (Dohn 2007, s. 43). Opfattelser af, hvad der appellerer til studerende, almindelig nysgerrighed, brugervenlighed og skabelse af vigtigt materiale for fremtidens historikere spiller blandt andet ind sammen med økonomiske overvejelser. Sidstnævnte kan selvsagt overtrumfe andre grunde til at udforme en teknologi på en særlig måde, og det er her, en mulig bekymring kan og bør melde sig hos undervisere, der må antages at ønske at udvikle redskaber, der primært støtter de pædagogiske og faglige mål.

\section{Konklusion}

Den viden, der kræves for at forstå muligheder og farer i brugen af teknologi, opnås bedst gennem empiriske studier af stærkt sammenlignelige fænomener, nøje beskrivelse af de evner, der er på spil, for så vidt man udvikler ny undervisning, udvikling af mere eller mindre formelle "teknologi-politikker « ${ }^{11}$ og ikke mindst gennem aktiv brug af den relevante teknologi. Hverken henvisning til maskinstormeri eller til determinisme er frugtbart i sammenhæng med diskussion af nye tiltag. Der er mange muligheder for handlen og indflydelse inden nogen blæser til maskinstorm - og udsigten til »krig«bør ikke spille nogen stor rolle under eventuelle "diplomatiske manøvrer" blandt universiteters undervisere. De diplomatiske manøvrer består her $i$ at præge en teknologi, således at éns interesser der for universitetsansattes vedkommende på lang sigt må antages at være sammenfaldende med det øvrige samfunds interesser - tilgodeses. Frit efter førnævnte podcast-ekspert, Karin Høgh, må man derfor sige: Se nu at komme igang med podcasting - der er noget at frygte.

\section{Referencer}

Braverman, H. (1974). Labor and Monopoly Capital: The Degradation of Work in the Twentieth Century. New York: Monthly Review Press

Dohn, N. B. (2007). IT-baserede læreprocesser - nogle muligheder og begrænsninger. Dansk Universitetspadagogisk Tidsskrift, 4

Feenberg, A. (2001). Whither Educational Technology? International Journal of Technology and Design Education, 11

Gooday, G. (1998). Taking Apart the 'Roads Ahead': User power Versus the Futurology of IT. Convergence, 4

Hamilton, E., \& Feenberg, A. (2005). The Technical Codes of Online Education. Techné 9:1

Leitch, V. B. (2005). Work Theory. Critical Inquiry, 31, 2

Mackenzie, D. (1996). Marx and the Machine. In Knowing Machines: Essays on Technical Change. Cambridge, MA: The MIT Press

Marx, K. (1971). Kapitalen. I J. Witt-Hansen (red.) København: Rhodos.

Noble, D. (2002). Digital Diploma Mills: The Automation of Higher Education. Toronto: Between the Lines Press

Perregaard, H. P. (2000). Økonomisk Teorihistorie $i$ et Humanistisk Perspektiv. Systime

Petrina, S. (2004). Sidney Pressey and the Automation of Education, 1924-1934. Technology and Culture, 45, 2

Platon (1936). Platons Skrifter Sjette Bind. København: C.A. Reitzels Forlag

Simmons, J. (2001). Educational Technology and Academic Freedom. Techne. 5, 3

Thyssen, O. (1985). Teknokosmos - om teknik og menneskerettigheder. København: Gyldendal

Winner, L. (1977). Autonomous Technology: Technics-out-of-Control as a Theme in Political Thought. Cambridge, MA:The MIT Press

Winner, L. (1986). Do Artefacts have Politics? In The Whale and the Reactor: A Search for Limits in an Age of High Technology. Chicago: University of Chicago Press

Winner, L. (1997). The Handwriting on the Wall: Resisting Technoglobalism's Assault on Education. In Marita Moll (ed.). Tech High: Globalization and the Future of Canadian Education, Ottawa: Fernwood Publication

Wood, A. (2004). Karl Marx. 2. udgave. London: Routledge.

Wulff, W. A. (1998). University alert: The information railroad is coming. Virginia.edu 2, 2.

\section{Noter}

1 En tilgængelig gennemgang af Marx' økonomiske teori kan findes i Perregaard (2000).

2 En proces som især 1970'erne var genstand for megen opmærksomhed og kritik fra Radical Science bevægelsen. Se f.eks. Braverman (1974), der med Marx som baggrund undersøgte udviklingen af arbejdsprocesser i første halvdel af det 20. århundrede.

3 Thyssens (1985) oversættelse »dekvalificering« kan bruges, når blot det huskes, at den dekvalificerede arbejder netop stadig er fuldt kvalificeret $\mathrm{i}$ forhold til det arbejde, han skal udføre. Arbejde spiller en central rolle i Marx' filosofiske antropologi, og gennemgribende ændringer i karakteren af arbejdet kan ifølge Marx forarme arbejderen på flere punkter og gøre ham ude af stand til at udføre noget, der er af afgørende betydning for mennesker.

4 En god gennemgang findes i Wood (2004). 
5 "Luddisme« er siden blevet synonymt med ekstrem modstand overfor teknologisk udvikling. Begrebet er dukket op igen hos Langdon Winner (1977), der forsøger at udvikle en strategi, han kalder "epistemologisk luddisme", som respons til teknologiers stærke gensidige afhængighed og deraf følgende tab af kontrol over teknologierne.

6 Professor Niels Egelund fra Danmarks Pædagogiske Universitet taler således om "gammelt maskinstormeri« i sin karakteristik af kollegaer, der er skeptiske over for podcasting af undervisning. (»Professor: Modstand er maskinstormeri« 24 timer Xtra, 19.10.2007, s. 8)

7 Inden for filosofien er der en vægtig præcedens for en skeptisk holdning over for nye teknologier inden for læring: I den intime samtale mellem lærer og elev skitseret i Faidros lader Platon Sokrates kritisere skriften for dens manglende evne til at reproducere den særlige dynamik i det talte ord. Se Platon (1936, 274c ff.)
8 I forbindelse med denne og næste paragraf, se især Hamilton \& Feenberg 2005.

9 Dette begreb - en variant af "deskilling - bruges i danske diskussioner af konsekvensen af den stærke afhængighed, flere institutter står i til løst ansatte undervisere, der typisk er ansat uden forskningsforpligtelse. Se fx "Verdens rigeste Universiteter - hovedproblemet er løsansættelser« (Forskerforum 01.04.2008, s. 27).

10 Se fx Feenbergs (1995, s. 123ff.) studium af franskmændenes rekonfigurering af det offentliges Minitel Videotext System. Intentionen bag introduktionen af teknologien havde næppe inkluderet muligheden for online chat, men handlede mest centralt om at give borgere mulighed for hurtig adgang til informationer leveret af det offentlige.

11 En sådan er bl.a. udarbejdet af San Diego's State University Faculty. Se http://www-rohan.sdsu.edu/faculty/feenberg/sdsudisted.html. 